\title{
man \\ Optimization of Train Energy Cooperation Using Scheduled Service Time Reserve
}

\author{
Michał Urbaniak ${ }^{1, *(1)}$ and Ewa Kardas-Cinal ${ }^{2}$ (]) \\ 1 Faculty of Civil and Environmental Engineering, Gdansk University of Technology, 80-233 Gdansk, Poland \\ 2 Faculty of Transport, Warsaw University of Technology, 00-661 Warszawa, Poland; \\ ewa.kardascinal@pw.edu.pl \\ * Correspondence: michal.urbaniak@pg.edu.pl
}

Citation: Urbaniak, M.; Kardas-Cinal,

E. Optimization of Train Energy

Cooperation Using Scheduled

Service Time Reserve. Energies 2022,

15, 119. https://doi.org/10.3390/

en15010119

Academic Editor: Adel Merabet

Received: 26 November 2021

Accepted: 22 December 2021

Published: 24 December 2021

Publisher's Note: MDPI stays neutral with regard to jurisdictional claims in published maps and institutional affiliations.

Copyright: (C) 2021 by the authors. Licensee MDPI, Basel, Switzerland. This article is an open access article distributed under the terms and conditions of the Creative Commons Attribution (CC BY) license (https:// creativecommons.org/licenses/by/ $4.0 /)$.

\begin{abstract}
The main aim of the paper was to develop an innovative approach to the preliminary estimation possibility of train energy cooperation based on data from timetables, without traction calculations. The article points out the need to strive for sustainable and environmentally friendly transport. It was pointed out that rail transport using electric traction is one of the more ecological branches of transport. It also offers a number of possibilities for improving energy efficiency and reducing energy consumption, one of which is the recovery and reuse of energy lost in the electrodynamic braking process. The main ways in which such energy can be used are listed, but the focus is mainly on the aspect of the so-called "energy cooperation" of trains. Then, the current state of the research and knowledge on the narrowed scope of rail traffic management and recuperative braking in rail transportation is presented; an innovative approach to the indirect optimization of the amount of recuperated electrical energy immediately usable by another vehicle by maximizing the duration of energy co-optimization is proposed; and the authors' function is proposed to enable optimization, taking into account various parameters. The optimization was performed with the use of a proprietary, multi-criteria objective function and the Solver optimization module. Finally, the results obtained using the proposed approach are presented and illustrated with the example of train timetables used by some of the largest railway stations in Poland.
\end{abstract}

Keywords: railway; transport; timetabling; energy recuperation; optimization; the impact of transport on the environment; electrification of transport systems

\section{Introduction}

In recent years, significant importance has been placed on both the development of innovative technologies for the production of so-called "green energy" and on reducing the energy consumption of the economy, one of the main elements of which is transport. An analysis of the economy of the 28 EU Member States has shown that in 2014, the main consumers of energy were households $(40.3 \%)$ and transport (31.8\%). The transport industry is also directly responsible for $19 \%$ of greenhouse gas emissions, which places it in second place in this classification, behind the closely related energy industry [1]. This, among other factors, is because a large portion of the electricity produced comes from coal power plants. Their share in energy production in countries such as Germany, France, or Spain is around $15 \%$, but in countries such as Poland, the share of energy derived from coal combustion is as high as 70\% [2].

Railway transport using electric traction (both conventional electric locomotives and multiple units and those fitted with on-board battery packs) is considered one of the more environmentally friendly branches of transport [3]. Taking into account climate change and its impact on the comfort of human life [4-6], and numerous legal documents not only aimed at reducing the environmental impact of transport activities $[1,7,8]$, but also by encouraging a switch to green energy, for example by providing loans on favorable terms [9] 
or tax breaks [10], railway transport should be used as much as possible, while reducing the share of other, non-green transport modes, such as air transport or road transport.

The undisputed advantages of rail transport, in addition to lower environmental costs, are the economic benefits resulting from, for example, lower energy consumption. In the case of using mainly electrified rail transport with regenerative braking in land transport instead of road transport, the reduction in energy-related costs can be nearly $30 \%$ [11].

However, we should not be satisfied with the current advantage of rail over other modes of transport in terms of low environmental impact. One of ways to reduce the electricity consumption of train operations includes the use of energy recovered during electrodynamic braking [12-14], which, when combined, for e.g., with automatic train control systems [15], can have significant benefits. The energy thus recovered may be reused in many ways, starting from supplying the vehicle's non-traction needs (e.g., lighting, heating, air-conditioning, and other on-board devices) through storing it in on-board or stationary energy storage tanks and using it later for any energy needs, to sending energy to the national power supply system or back to the rail overhead contact network [16].

Therefore, the order in which the recovered energy is used is also important. This has an impact on the additional infrastructure costs potentially incurred for the utilization of electricity (e.g., the cost of constructing energy storage facilities or additional traction substations). It is worth noting that only the transfer of the energy recovered during electrodynamic braking back to the contact line-thus increasing its voltage and its utilization by other trains in the same power supply section (usually the area adjacent to the station) gives the possibility of the potentially cost-free management of larger amounts of excess energy [17,18].

In this work, indirect consideration was given to the question of the possibility and optimization of the amount of energy recovered during the electrodynamic braking of a train in close vicinity of a railway station, and maximizing the time during which this energy can be used directly by another train in the same power supply section, using the operating time reserve included in the train timetable. For the purpose of briefly describing the above situation, the term "energy cooperation" was introduced.

It was also hypothesized that, while from the point of view of energy management in the power supply system, specific information on the value of consumed and recuperated energy is absolutely necessary, from the point of view of planning and the development of the timetable, it is the information based on the departure and arrival times of trains that determines when the energy cooperation of trains is possible and to what degree can be sufficient.

The method presented in the article may indirectly contribute to the attractiveness of rail transport in economic and environmental terms.

\section{Literature Review}

The issue of rail traffic management involves many components. They include [19-21]:

- Line Planning Problem (LPP)—involves defining a set of train routes and their frequencies so that they meet customer expectations to the maximum extent. In order to formulate the mathematical problem, it is necessary to determine the linear and nodal elements of the infrastructure, the train running times, and the demand volume.

- Train Timetabling Problem or Train Scheduling Problem (TTP/TSP)—consists of determining, for a given set of trains, that the running frequency, the departure times from the departure station for each train, the arrival and departure time at each station in such a way that safety is ensured, minimum travel time and maximum profit are met. This problem can be considered in the context of both cyclic and non-cyclic timetables.

- Train Platforming Problem (TPP) - the solution to this problem makes it possible to work out the path of each train passing along the track layout of the station with the highest level of safety, taking into account minimal time intervals between particular vehicles. 
- The Rolling Stock Circulation Problem (RSCP) - the solution to this problem is to assign each train a vehicle to provide a service in such a way that the cost of providing the service, as well as the amount of rolling stock required, is as low as possible.

- Planning the work of train operation crews-involves assigning train crews to planned trains at the lowest possible cost of task execution and taking into account a number of constraints.

The optimization of railway traffic management, according to the criterion of minimum costs, should take into account, among others [22,23]:

- the real-time optimization of train traffic with a view to minimizing energy consumption and train delays;

- the optimization of driving techniques for train drivers;

- the optimization of the number of trains operating on the routes in terms of empty mileage costs; and

- the optimization of the work schedule of conductor crews and train crews, taking into account their maintenance costs.

An extremely important effect of choosing appropriate criteria in the algorithm of improving railway transport management may turn out to be the reduction (direct and indirect) of greenhouse gas emissions, including $\mathrm{CO}_{2}$, into the atmosphere. The optimization of train traffic from the point of view of reducing energy consumption fits perfectly into the idea of reducing the energy intensity of rail transport [24], which is emphasized in European Union (EU) policy.

The use of recuperated energy by another vehicle is technically connected with a necessity to feed back the energy recovered during braking into the overhead contact line. There should also be a traffic situation with at least one supplying (braking) vehicle and at least one receiving (accelerating) vehicle on one supply section. Because most modern rail transport systems allow recovered energy to be fed back into the overhead contact line, this method can be described as being mostly cost-free and without any significant interference in infrastructure. However, it should be noted that to obtain the best benefits in the improvement of energy balance, the optimization of timetables or the adaptive control of vehicles should be used for the purpose of increasing the positive effects of recuperative braking [25]. From the point of view of railway traffic management, this issue is related to LPP and TTP/TSP and fits perfectly into the strategy of the train traffic optimization in real time, taking into account energy savings or optimizing driving techniques for drivers.

Optimizing the use of energy from recuperation by synchronizing the start-up and braking times has many advantages, including the potentially low cost, direct impact on traction energy consumption, and reduction of the occurrence of energy peaks, providing the start-up of several trains at the same time is eliminated. The authors of [26] also noted that the greatest opportunities for the use, development, and improvement of this technology are dense urban rail transport networks like SKM trains (fast urban rail), underground trains (metro), or trams. In these cases, there is frequent and often cyclical rail traffic that does not require significant shifts in the timetable for the synchronization of acceleration and braking times.

As early as 2010, Nasri and his team [27] showed that in metro line systems, up to $14 \%$ of the traction energy could be saved by using appropriate timetable optimization. They obtained this result using genetic algorithms and exploiting technical time reserves for maximizing the use of energy from recovery braking.

In 2011, Pena-Alcaraz and her team [28] designed a new timetable for the third metro line in Madrid. The result of the introduction of the proposed timetable was a reduction in energy consumption of 3\% after only one week. They obtained this result by solving a non-linear mixed integer optimization problem, and claim that the result could be further improved by another $7 \%$.

In 2014, Yang and his team [29], using timetable data from the Beijing Yizhuang (China) subway line, showed that both the passenger waiting time for trains and the electricity consumed can be reduced by $3.22 \%$ and $8.86 \%$, respectively, compared to the current 
timetable. The authors compared the current timetable with a timetable formulated using two-criteria optimization (with two criteria: energy savings and waiting time for a train) using a genetic algorithm with binary coding, which led to the above results.

In the literature, we can also find examples of optimizing energy consumption by storing recovered energy in on-board and stationary energy storage, or transferring energy to the national power supply system [13]. Analyses of on-board energy storages in the literature show that their use can reduce the costs of the traction energy consumed by $15 \%$ to $35 \%$ [30-32]. Moreover, the results of using stationary supercapacitor batteries may give similar energy savings of $18 \%$ to $36 \%[30,33]$. On the other hand, the resale of recovered energy to the national power supply system enables savings of 7\% to $14 \%$ [34-36]. However, these are net savings, which do not take into account the costs of specialized vehicle equipment and the construction of new infrastructure.

It should be noted that the analyses presented in the literature concern mainly metro lines. It is equally important to note that all of the above-mentioned developed algorithms are mostly based on relatively complicated traction calculations, and carry out the so-called theoretical drive to calculate specific energy values. In the following sections, an innovative and universal model is presented that allows the estimation of the possibility of train energy cooperation based on the times included in the train timetable without the need to make traction calculations.

\section{Materials and Methods}

\subsection{Model}

The following condition (1) has to be fulfilled for the organized energy cooperation of train groups in a station without the need for a timetable change.

$$
\mathrm{t}_{\mathrm{rr}}^{\min }\left(\mathrm{p}_{\mathrm{i}}, \mathrm{s}_{\mathrm{k}}\right)<\mathrm{t}_{\mathrm{kh}}^{\max }\left(\mathrm{p}_{\mathrm{j}}, \mathrm{s}_{\mathrm{k}}\right) \text { and } \mathrm{t}_{\mathrm{rh}}^{\min }\left(\mathrm{p}_{\mathrm{j}}, \mathrm{s}_{\mathrm{k}}\right)<\mathrm{t}_{\mathrm{kr}}^{\max }\left(\mathrm{p}_{\mathrm{i}}, \mathrm{s}_{\mathrm{k}}\right)
$$

where $p_{i}$ means the number of the $i$-th departing train $p, p_{j}$ means the number of the $j$-th arriving train $\mathrm{p}, \mathrm{s}_{\mathrm{k}}$ is the number of the $\mathrm{k}$-th station $\mathrm{s}, \mathrm{trr}_{\mathrm{rr}}^{\min }\left(\mathrm{p}_{\mathrm{i}}, \mathrm{s}_{\mathrm{k}}\right)$ is the earliest start-up initiation time of the $\mathrm{i}$-th train $\mathrm{p}$ departing from station $\mathrm{s}, \mathrm{t}_{\mathrm{kh}}^{\max }\left(\mathrm{p}_{\mathrm{j}}, \mathrm{s}_{\mathrm{k}}\right)$ is the latest end time of braking of the $j$-th train $p$ arriving at station $s, t_{r h}^{\min }\left(p_{j^{\prime}}, s_{k}\right)$ is the earliest time of the braking initiation of the $\mathrm{j}$-th train $\mathrm{p}$ arriving at $\mathrm{k}$-th station $\mathrm{s}$, and $\mathrm{t}_{\mathrm{kr}}^{\max }\left(\mathrm{p}_{\mathrm{i}}, \mathrm{s}_{\mathrm{k}}\right)$ is the latest end time of the start-up of the i-th train $p$ departing from station $s$.

The earliest initiation time and the latest end time of the start-up of the i-th train $p$ departing from station s can be described by relations (2) and (3), respectively.

$$
\begin{gathered}
\mathrm{t}_{\mathrm{rr}}^{\min }\left(\mathrm{p}_{\mathrm{i}}, \mathrm{s}_{\mathrm{k}}\right)=\mathrm{t}_{\mathrm{odj}}\left(\mathrm{p}_{\mathrm{i}}, \mathrm{s}_{\mathrm{k}}\right) \\
\mathrm{t}_{\mathrm{kr}}^{\max }\left(\mathrm{p}_{\mathrm{i}}, \mathrm{s}_{\mathrm{k}}\right)=\mathrm{t}_{\mathrm{odj}}\left(\mathrm{p}_{\mathrm{i}}, \mathrm{s}_{\mathrm{k}}\right)+\mathrm{t}_{\mathrm{b}}^{\max }\left(\mathrm{p}_{\mathrm{i}}, \mathrm{s}_{\mathrm{k}}\right)+\mathrm{t}_{\mathrm{r}}\left(\mathrm{p}_{\mathrm{i}}, \mathrm{v}_{\mathrm{h}}\left(\mathrm{p}_{\mathrm{i}}\right)\right)
\end{gathered}
$$

where $t_{\text {odj }}\left(p_{i}, s_{k}\right)$ means the scheduled time of departure of the $i$-th train $p$ from the k-th station $\mathrm{s}, \mathrm{t}_{\mathrm{b}}^{\max }\left(\mathrm{p}_{\mathrm{i}}, \mathrm{s}_{\mathrm{j}}\right)$ is the technical operating time reserve in the timetable for the $\mathrm{i}$-th train $\mathrm{p}$ departing from the $\mathrm{k}$-th station $\mathrm{s}, \mathrm{t}_{\mathrm{r}}\left(\mathrm{p}_{\mathrm{i}}, \mathrm{v}_{\mathrm{h}}\left(\mathrm{p}_{\mathrm{i}}\right)\right)$ is the minimum start-up time of the $\mathrm{i}$-th train $\mathrm{p}$ from speed equal 0 to commercial speed $\mathrm{v}_{\mathrm{h}}$, and $\mathrm{v}_{\mathrm{h}}\left(\mathrm{p}_{\mathrm{i}}\right)$ is the commercial speed of the i-th train $p$ departing from the k-th station $\mathrm{s}$.

The earliest braking start time and the latest braking end time of the $j$-th train $p$ arriving at the k-th station s can be described by relations (4) and (5), respectively.

$$
\begin{gathered}
\mathrm{t}_{\mathrm{rh}}^{\min }\left(\mathrm{p}_{\mathrm{j}}, \mathrm{s}_{\mathrm{k}}\right)=\mathrm{t}_{\text {przyj }}\left(\mathrm{p}_{\mathrm{j}}, \mathrm{s}_{\mathrm{k}}\right)-\mathrm{t}_{\mathrm{h}}\left(\mathrm{p}_{\mathrm{j}}, \mathrm{v}_{\mathrm{h}}\left(\mathrm{p}_{\mathrm{j}}\right)\right) \\
\mathrm{t}_{\mathrm{kh}}^{\max }\left(\mathrm{p}_{\mathrm{j}}, \mathrm{s}_{\mathrm{k}}\right)=\mathrm{t}_{\text {odj }}\left(\mathrm{p}_{\mathrm{j}}, \mathrm{s}_{\mathrm{k}}\right)+\mathrm{t}_{\mathrm{b}}^{\max }\left(\mathrm{p}_{\mathrm{j}}, \mathrm{s}_{\mathrm{k}}\right)+\mathrm{T}_{\mathrm{wp}}\left(\mathrm{p}_{\mathrm{j}}, \mathrm{s}_{\mathrm{k}}\right)
\end{gathered}
$$

where $t_{\text {przyj }}\left(p_{j}, s_{k}\right)$ is the scheduled arrival time of the $j$-th train $p$ at the k-th station $s$, $t_{h}\left(p_{j}, v_{h}, p_{i}\right)$ is the minimum braking time of the $j$-th train $p$ from the commercial speed $v_{h}$ 
until it stops, $\mathrm{v}_{\mathrm{h}}\left(\mathrm{p}_{\mathrm{j}}\right)$ is the commercial speed of the $\mathrm{j}$-th train $\mathrm{p}$ arriving at the $\mathrm{k}$-th station $s, t_{b}^{\max }\left(p_{j}, s_{k}\right)$ is the maximum usable technical time reserve in the timetable for the $j$-th train $\mathrm{p}$ arriving at the $\mathrm{k}$-th station $\mathrm{s}$, and $\mathrm{T}_{\mathrm{wp}}\left(\mathrm{p}_{\mathrm{j}}, \mathrm{s}_{\mathrm{k}}\right)$ is the minimum time needed to change passengers after the arrival of train $\mathrm{j}$ at station $\mathrm{k}$.

Therefore, having data $S$ as a set of station and stop numbers, $\mathrm{P}$ as a set of train numbers $p_{i}$ and $p_{j}$ served by the station $s_{k} \in S, t_{o d j}\left(p_{i}, s_{k}\right), t_{\text {przyj }}\left(p_{j}, s_{k}\right), t_{h}\left(p_{j}, v_{h}\right), T_{B}\left(p_{j}=j, s_{k}\right)$, it is possible to define pairs $(i, j)$ of trains between which energy cooperation can occur without modifying the current timetable (6).

$$
c\left(p_{i}, p_{j}, s_{k}\right)=\left\{\begin{array}{c}
1 \text { if } t_{r r}^{\min }\left(p_{i}, s_{k}\right)<t_{k h}^{\max }\left(p_{j}, s_{k}\right) \text { and } t_{r h}^{\min }\left(p_{j}, s_{k}\right)<t_{k r}^{\max }\left(p_{i}, s_{k}\right) \\
0 \text { otherwise }
\end{array}\right.
$$

where $c\left(p_{i}, p_{j}, s_{k}\right)$ is the energy coefficient of cooperation at $k$-th station $s$ between i-th and $j$-th train $p$, taking the value 1 if cooperation can take place, and the value 0 if cooperation cannot take place.

\subsection{Optimization Algorithm}

The decision variables of the global objective function were taken as:

$t_{b}\left(p_{i}, s_{k}\right)$-technical operating time reserve used in timetable for $i$-th train $p$ departing from $\mathrm{k}$-th station $\mathrm{s}_{\mathrm{k}}$,

$t_{b}\left(p_{j}, s_{k}\right)$ - technical operating time reserve used in timetable for $j$-th train $p$ arriving at $k$-th station $\mathrm{s}_{\mathrm{k}}$.

The sum of the time reserves used $t_{b}\left(p_{i}, s_{k}\right)$ and $t_{b}\left(p_{j}, s_{k}\right)$ for the same train, which first arrives on $\mathrm{k}$-th station $\mathrm{s}_{\mathrm{k}}$ (i.e., belongs to train group $\mathrm{j}$ ) and then departs from this station (i.e., belongs to train group i), cannot exceed the total technical time reserve for train $\mathrm{p}$.

$$
\mathrm{T}_{\mathrm{B}}\left(\mathrm{p}_{\mathrm{i}=\mathrm{j}}, \mathrm{s}_{\mathrm{k}}\right) \geq \mathrm{t}_{\mathrm{b}}\left(\mathrm{p}_{\mathrm{i}}, \mathrm{s}_{\mathrm{k}}\right)+\mathrm{t}_{\mathrm{b}}\left(\mathrm{p}_{\mathrm{j}}, \mathrm{s}_{\mathrm{k}}\right)
$$

where $\operatorname{TB}\left(p_{i}=j, s_{k}\right)$ is the total technical operating time reserve foreseen for train $p$.

As the first partial objective function, directly related to the efficiency of the use of energy cooperation, the sum of the trains that at a given station will participate in the process of supplying and receiving energy recovered during braking (8) was taken.

$$
\mathrm{F}_{1}=\sum_{i, j}\left(\mathrm{c}\left(\mathrm{p}_{\mathrm{i}}, \mathrm{p}_{\mathrm{j}}, \mathrm{s}_{\mathrm{k}}\right)\right) \rightarrow \max
$$

Since the balance of energy that can be supplied and received by the overhead contact line by the vehicles at the same time is closely related to the duration of energy cooperation among a group of vehicles (as shown in the literature review), it was decided to maximize this time to give the chance to achieve better effects of energy cooperation at a later stage. The second component of the objective function can therefore be considered to be the sum of all energy cooperation times of trains that take place at a given railway station (9). The longer the total time of energy cooperation, the more beneficial the energy balance can potentially be.

$$
\mathrm{F}_{2}=\sum_{i, j}\left(\mathrm{~T}_{\mathrm{EK}}\left(\mathrm{p}_{\mathrm{i}}, \mathrm{p}_{\mathrm{j}}, \mathrm{s}_{\mathrm{k}}\right)\right) \rightarrow \max
$$

In the above case, $\mathrm{T}_{\mathrm{EK}}\left(\mathrm{p}_{\mathrm{i}}, \mathrm{p}_{\mathrm{j}}, \mathrm{s}_{\mathrm{k}}\right)$ means the energy cooperation time of the departing $i$-th and arriving $j$-th trains $p$ at the $k$-th station $s_{k}$.

Taking into account $(1)$ in determining $\mathrm{T}_{\mathrm{EK}}\left(\mathrm{p}_{\mathrm{i}}, \mathrm{p}_{\mathrm{j}}, \mathrm{s}_{\mathrm{k}}\right)$, there are four key situations (Figure 1) in which the energy cooperation of trains should be considered. 


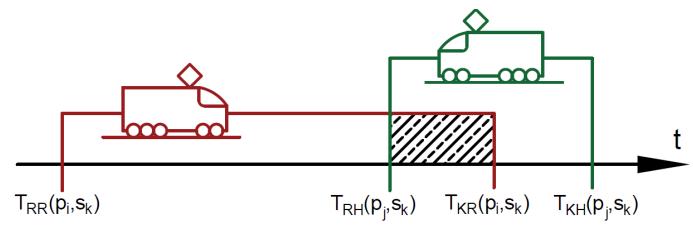

(a)

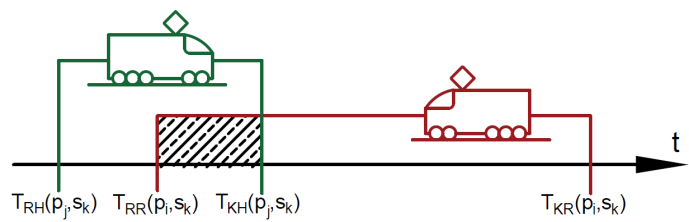

(c)

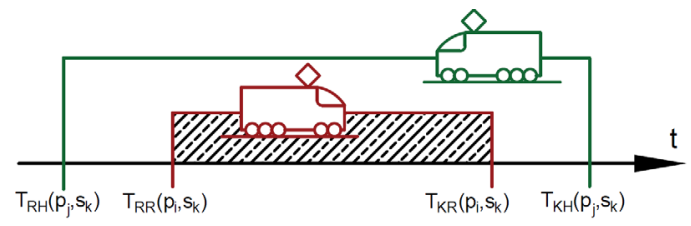

(b)

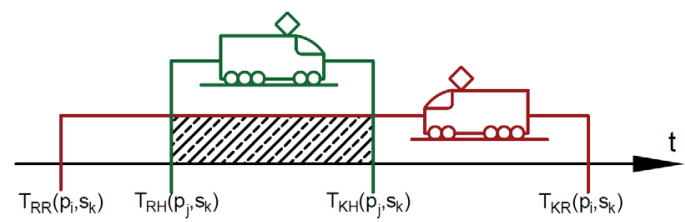

(d)

Figure 1. Each situations, (a-d), where the energy cooperation of trains is possible. Source: own study.

The situations presented above can be clarified using the following relationships:

1. For case (a), when the real braking start time of the $j$-th train is later than the real start-up time of the i-th train, but simultaneously earlier than the real end time of the i-th train's start-up and when the real braking end time of the $j$-th train is later than the real end time of the i-th train's start-up:

$$
\begin{gathered}
\text { if: } T_{R R}\left(p_{i}, s_{k}\right) \leq T_{R H}\left(p_{j}, s_{k}\right) \leq T_{K R}\left(p_{i}, s_{k}\right) \leq T_{K K}\left(p_{j}, s_{k}\right) \\
\text { then : } T_{E K}\left(p_{i}, p_{j}, s_{k}\right)=T_{K R}\left(p_{i}, s_{k}\right)-T_{R H}\left(p_{j}, s_{k}\right)
\end{gathered}
$$

where:

$\mathrm{T}_{\mathrm{RR}}\left(\mathrm{p}_{\mathrm{i}}, \mathrm{s}_{\mathrm{k}}\right)$ - actual time of the start-up initiation of the i-th train $\mathrm{p}$ to commercial speed $\mathrm{v}_{\mathrm{h}}$, enabling the implementation of the timetable without secondary delays at station $\mathrm{s}_{\mathrm{k}+1}$ (larger than $\mathrm{TB}\left(\mathrm{p}_{\mathrm{i}}={ }_{\mathrm{j}}, \mathrm{s}_{\mathrm{k}}\right)$ ),

$\mathrm{T}_{\mathrm{RH}}\left(\mathrm{p}_{\mathrm{j}}, \mathrm{s}_{\mathrm{k}}\right)$-real time of braking initiation of the $\mathrm{j}$-th train $\mathrm{p}$ from commercial speed $\mathrm{v}_{\mathrm{h}}$, enabling the implementation of the timetable without secondary delays at station $\mathrm{s}_{\mathrm{k}+1}$ (larger than $\mathrm{T}_{\mathrm{B}}\left(\mathrm{p}_{\mathrm{i}}=\mathrm{j}, \mathrm{s}_{\mathrm{k}}\right)$ ),

$T_{K R}\left(p_{i}, s_{k}\right)$-real time end of the start-up of $i$-th train $p$ to commercial speed $v_{h}$ enabling the implementation of the timetable without secondary delays in station $\mathrm{s}_{\mathrm{k}+1}$ (bigger than $\mathrm{T}_{\mathrm{B}}\left(\mathrm{p}_{\mathrm{i}}=\mathrm{j}, \mathrm{s}_{\mathrm{k}}\right)$ ),

$\mathrm{T}_{\mathrm{KH}}\left(\mathrm{p}_{\mathrm{j}}, \mathrm{s}_{\mathrm{k}}\right)$-actual end time of braking of $\mathrm{j}$-th train $\mathrm{p}$ from commercial speed $\mathrm{v}_{\mathrm{h}}$, enabling the implementation of the timetable.

whereas:

- the actual initiation time of the start-up phase of the i-th train $\mathrm{T}_{\mathrm{RR}}\left(\mathrm{p}_{\mathrm{i}}, \mathrm{s}_{\mathrm{k}}\right)$ can be determined from relation (2):

$$
\begin{gathered}
\mathrm{T}_{\mathrm{RR}}\left(\mathrm{p}_{\mathrm{i}}, \mathrm{s}_{\mathrm{k}}\right) \in \mathrm{t}_{\mathrm{rr}}^{\min }\left(\mathrm{p}_{\mathrm{i}}, \mathrm{s}_{\mathrm{k}}\right) ; \mathrm{t}_{\mathrm{rr}}^{\max }\left(\mathrm{p}_{\mathrm{i}}, \mathrm{s}_{\mathrm{k}}\right) \\
\mathrm{t}_{\mathrm{rr}}^{\min }\left(\mathrm{p}_{\mathrm{i}}, \mathrm{s}_{\mathrm{k}}\right)=\mathrm{t}_{\mathrm{odj}}\left(\mathrm{p}_{\mathrm{i}}, \mathrm{s}_{\mathrm{k}}\right)+\mathrm{t}_{\mathrm{b}}\left(\mathrm{p}_{\mathrm{i}}, \mathrm{s}_{\mathrm{k}}\right)
\end{gathered}
$$

where $t_{r r}{ }^{\max }\left(p_{i}, s_{k}\right)$ is the latest possible start-up initiation time for the $i$-th train $p_{i}$ departing from the $\mathrm{k}$-th station $\mathrm{s}_{\mathrm{k}}$.

- the actual initiation time of the braking phase of the $j$-th train $T_{R H}\left(p_{j}, s_{k}\right)$ can be determined by means of relation (4):

$$
\begin{gathered}
\mathrm{T}_{\mathrm{RH}}\left(\mathrm{p}_{\mathrm{j}}, \mathrm{s}_{\mathrm{k}}\right) \in \mathrm{t}_{\mathrm{rh}}^{\min }\left(\mathrm{p}_{\mathrm{j}}, \mathrm{s}_{\mathrm{k}}\right) ; \mathrm{t}_{\mathrm{rh}}^{\max }\left(\mathrm{p}_{\mathrm{j}}, \mathrm{s}_{\mathrm{k}}\right) \\
\mathrm{t}_{\mathrm{rh}}^{\max }\left(\mathrm{p}_{\mathrm{j}}, \mathrm{s}_{\mathrm{k}}\right)=\mathrm{t}_{\mathrm{przyj}}\left(\mathrm{p}_{\mathrm{j}}, \mathrm{s}_{\mathrm{k}}\right)+\mathrm{t}_{\mathrm{b}}\left(\mathrm{p}_{\mathrm{j}}, \mathrm{s}_{\mathrm{k}}\right)-\mathrm{t}_{\mathrm{h}}\left(\mathrm{p}_{\mathrm{j}}, \mathrm{v}_{\mathrm{h}}\left(\mathrm{p}_{\mathrm{j}}\right)\right)
\end{gathered}
$$


where $t_{r h}^{\max }\left(p_{i}, s_{k}\right)$ is the latest possible braking initiation time for the $j$-th train $p_{j}$ entering the $\mathrm{k}$-th station $\mathrm{s}_{\mathrm{k}}$,

- the real end time of the start-up phase of the $\mathrm{i}$-th train $\mathrm{T}_{\mathrm{KR}}\left(\mathrm{p}_{\mathrm{i}}, \mathrm{s}_{\mathrm{K}}\right)$ can be determined from relation (3):

$$
\begin{gathered}
\mathrm{T}_{\mathrm{KR}}\left(\mathrm{p}_{\mathrm{i}}, \mathrm{s}_{\mathrm{k}}\right) \in \mathrm{t}_{\mathrm{kr}}^{\min }\left(\mathrm{p}_{\mathrm{i}}, \mathrm{s}_{\mathrm{k}}\right) ; \mathrm{t}_{\mathrm{kr}}^{\max }\left(\mathrm{p}_{\mathrm{i}}, \mathrm{s}_{\mathrm{k}}\right) \\
\mathrm{t}_{\mathrm{kr}}^{\min }\left(\mathrm{p}_{\mathrm{i}}, \mathrm{s}_{\mathrm{k}}\right)=\mathrm{t}_{\mathrm{odj}}\left(\mathrm{p}_{\mathrm{i}}, \mathrm{s}_{\mathrm{k}}\right)+\mathrm{t}_{\mathrm{r}}\left(\mathrm{p}_{\mathrm{i}}, \mathrm{v}_{\mathrm{h}}\left(\mathrm{p}_{\mathrm{i}}\right)\right)
\end{gathered}
$$

where $t_{\mathrm{kr}}^{\min }\left(\mathrm{p}_{\mathrm{i}}, \mathrm{s}_{\mathrm{k}}\right)$ is the earliest possible start-up end time for the $\mathrm{i}$-th train $\mathrm{p}$ departing from the k-th station $\mathrm{s}_{\mathrm{k}}$

- the actual end time of the braking phase of the $j$-th train $T_{R H}\left(p_{j}, s_{k}\right)$ can be determined by means of relation (5):

$$
\begin{gathered}
\mathrm{T}_{\mathrm{KH}}\left(\mathrm{p}_{\mathrm{j}}, \mathrm{s}_{\mathrm{k}}\right) \in \mathrm{t}_{\mathrm{kh}}^{\min }\left(\mathrm{p}_{\mathrm{j}}, \mathrm{s}_{\mathrm{k}}\right) ; \mathrm{t}_{\mathrm{kh}}^{\max }\left(\mathrm{p}_{\mathrm{j}}, \mathrm{s}_{\mathrm{k}}\right) \\
\mathrm{t}_{\mathrm{kh}}^{\min }\left(\mathrm{p}_{\mathrm{j}}, \mathrm{s}_{\mathrm{k}}\right)=\mathrm{t}_{\mathrm{przyj}}\left(\mathrm{p}_{\mathrm{j}}, \mathrm{s}_{\mathrm{k}}\right)
\end{gathered}
$$

where $t_{\mathrm{kh}}^{\min }\left(\mathrm{p}_{\mathrm{j}}, \mathrm{s}_{\mathrm{k}}\right)$ is the earliest possible braking end time for the $\mathrm{j}$-th train $\mathrm{p}_{\mathrm{j}}$ entering the $\mathrm{k}$-th station $\mathrm{s}_{\mathrm{k}}$.

2. For case (b), when the actual braking initiation time of the $\mathrm{j}$-th train is earlier than the real start-up initiation time of the i-th train and, at the same time, when the start-up end time of the $\mathrm{i}$-th train is earlier than the actual braking end time of the j-th train:

$$
\begin{gathered}
\text { if : } T_{R H}\left(p_{j^{\prime}}, s_{k}\right) \leq T_{R R}\left(p_{i}, s_{k}\right) \text { and } T_{K R}\left(p_{i}, s_{k}\right) \leq T_{R R}\left(p_{j}, s_{k}\right) \\
\text { then : } T_{E K}\left(p_{i}, p_{j}, s_{k}\right)=T_{K R}\left(p_{i}, s_{k}\right)-T_{R R}\left(p_{i}, s_{k}\right)
\end{gathered}
$$

3. For case (c), when the real start-up initiation time of the j-th train is later than the real initiation time of the i-th train's breaking, but is simultaneously earlier than the real end time of the i-th train's braking and when the real end time of the j-th train's start-up is later than the real end time of the i-th train's braking:

$$
\begin{aligned}
\text { if: } T_{R H}\left(p_{j^{\prime}}, s_{k}\right) \leq T_{R R}\left(p_{i}, s_{k}\right) \leq T_{K H}\left(p_{j}, s_{k}\right) \leq T_{K R}\left(p_{i}, s_{k}\right) \\
\text { then : } T_{E K}\left(p_{i}, p_{j}, s_{k}\right)=T_{K H}\left(p_{j}, s_{k}\right)-T_{R R}\left(p_{j}, s_{k}\right)
\end{aligned}
$$

4. For case (d), when the real start-up initiation time of the i0-th train is earlier than the real braking initiation time of the $j$-th train and, simultaneously, when the real braking end time of the $j$-th train is later than the real start-up end time of the i-th train:

$$
\begin{gathered}
\text { if: } \mathrm{T}_{\mathrm{RR}}\left(\mathrm{p}_{\mathrm{i}}, \mathrm{s}_{\mathrm{k}}\right) \leq \mathrm{T}_{\mathrm{RH}}\left(\mathrm{p}_{\mathrm{j}}, \mathrm{s}_{\mathrm{k}}\right) \text { and } \mathrm{T}_{\mathrm{KH}}\left(\mathrm{p}_{\mathrm{j}}, \mathrm{s}_{\mathrm{k}}\right) \leq \mathrm{T}_{\mathrm{KR}}\left(\mathrm{p}_{\mathrm{i}}, \mathrm{s}_{\mathrm{k}}\right) \\
\text { then : } \mathrm{T}_{\mathrm{EK}}\left(\mathrm{p}_{\mathrm{i}}, \mathrm{p}_{\mathrm{j}}, \mathrm{s}_{\mathrm{k}}\right)=\mathrm{T}_{\mathrm{KH}}\left(\mathrm{p}_{\mathrm{j}}, \mathrm{s}_{\mathrm{k}}\right)-\mathrm{T}_{\mathrm{RH}}\left(\mathrm{p}_{\mathrm{j}}, \mathrm{s}_{\mathrm{k}}\right)
\end{gathered}
$$

The second component of the global objective function was assumed to be the correspondence of the real train arrival time with the time given in the timetable, i.e., the arrival delay time:

$$
\mathrm{F}_{3}=\sum_{j}\left(\mathrm{~T}_{\mathrm{KH}}\left(\mathrm{p}_{\mathrm{j}}, \mathrm{s}_{\mathrm{k}}\right)-\mathrm{t}_{\mathrm{przyj}}\left(\mathrm{p}_{\mathrm{j}}, \mathrm{s}_{\mathrm{k}}\right)\right) \rightarrow \min
$$

The third component of the global objective function was assumed to be the correspondence of the real time of departure of trains with the time given in the timetable:

$$
\mathrm{F}_{4}=\sum_{i}\left(\mathrm{~T}_{\mathrm{RR}}\left(\mathrm{p}_{\mathrm{i}}, \mathrm{s}_{\mathrm{k}}\right)-\mathrm{t}_{\mathrm{odj}}\left(\mathrm{p}_{\mathrm{i}}, \mathrm{s}_{\mathrm{k}}\right)\right) \rightarrow \min
$$


The global weighted objective function was taken down as the weighted difference of the three components:

$$
\mathrm{FC}: \mathrm{F}_{\mathrm{G}}=\mathrm{w}_{1} \cdot \mathrm{F}_{1}+\mathrm{w}_{2} \cdot \mathrm{F}_{2}-\mathrm{w}_{3} \cdot \mathrm{F}_{3}-\mathrm{w}_{4} \cdot \mathrm{F}_{4}
$$

where $\mathrm{w}_{1}, \mathrm{w}_{2}, \mathrm{w}_{3}, \mathrm{w}_{4}$ are the weight factors of each function, where:

$$
\sum_{g} \mathrm{w}_{\mathrm{g}}=1 \text { and } \mathrm{w}_{\mathrm{g}} \in 0 ; 1
$$

\section{Results}

\subsection{General Assumptions and Data}

Optimization, according to the universal algorithm, can be used at any railway station or stop, but item 4 was performed for five selected large railway stations in Poland with different rail traffic characteristics. Small railway stations and stops were omitted from this analysis because of the low number of accelerating and braking trains in these areas. This means there is very low probability that energy cooperation between trains will be possible. The selected stations were:

- Gdańsk Główny railway station,

- Warszawa Wschodnia railway station,

- Wrocław Główny railway station,

- Poznań Główny railway station,

- Katowice railway station.

The main criterion for the selection of these stations was the maximum daily number of trains and passengers served, but their different organizational characteristics and their location in the country were also considered, as shown in Figure 2.

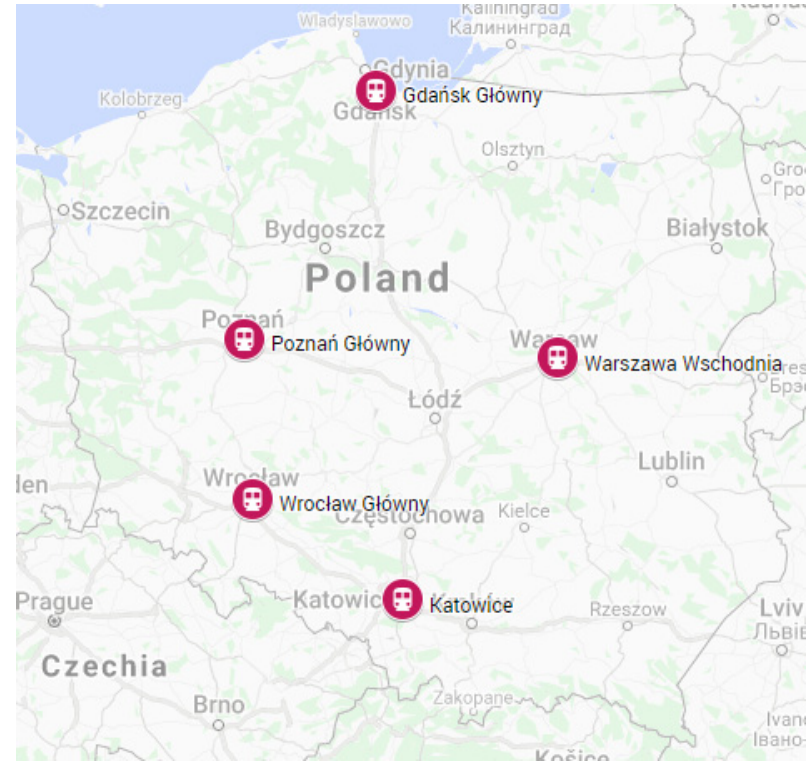

(a)

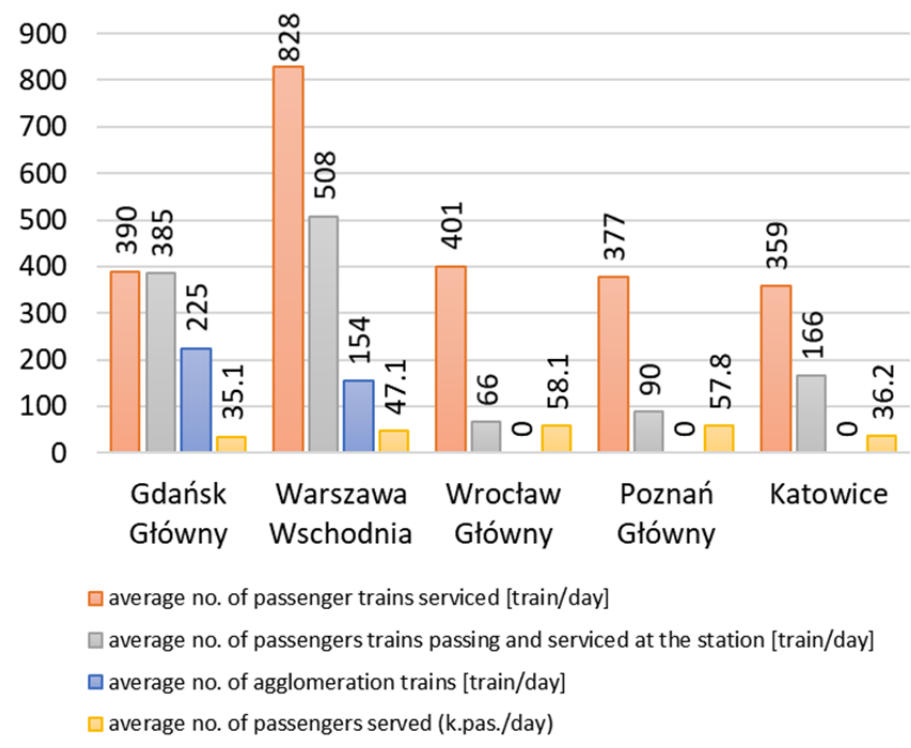

(b)

Figure 2. Characteristics of the selected railway stations. (a) Locations of selected railway stations. (b) Characteristics numbers of the selected railway stations. Source: own study based on [37-39].

The train timetable data for the stations listed as of 20 September 2021 were used for the purposes of optimization. An extract of the already compiled data, containing information on train number, train type, arrival time, and departure time, is shown in Table 1. 
Table 1. Extract from the train timetable in selected railway stations in Poland.

\begin{tabular}{|c|c|c|c|c|c|c|c|c|c|c|c|}
\hline \multicolumn{4}{|c|}{ Warszawa Wschodnia } & \multicolumn{4}{|c|}{ Gdańsk Główny } & \multicolumn{4}{|c|}{ Wrocław Główny } \\
\hline $\begin{array}{l}\text { Train } \\
\text { No. }\end{array}$ & $\begin{array}{c}\text { Type of } \\
\text { train }\end{array}$ & $\begin{array}{c}\text { Arrival } \\
\text { time }\end{array}$ & $\begin{array}{l}\text { Departure } \\
\text { time }\end{array}$ & $\begin{array}{l}\text { Train } \\
\text { No. }\end{array}$ & $\begin{array}{l}\text { Type of } \\
\text { train }\end{array}$ & $\begin{array}{c}\text { Arrival } \\
\text { time }\end{array}$ & $\begin{array}{l}\text { Departure } \\
\text { time }\end{array}$ & $\begin{array}{l}\text { Train } \\
\text { No. }\end{array}$ & $\begin{array}{c}\text { Type of } \\
\text { train }\end{array}$ & $\begin{array}{c}\text { Arrival } \\
\text { time }\end{array}$ & $\begin{array}{l}\text { Departure } \\
\text { time }\end{array}$ \\
\hline 19889 & $\mathrm{KM}$ & 00:03:00 & 00:04:00 & 95401 & SKM & 00:03:00 & 00:04:00 & 83172 & IC & 00:53:00 & 01:05:00 \\
\hline 19567 & $\mathrm{KM}$ & $00: 25: 00$ & $00: 26: 00$ & 59400 & SKM & 04:22:00 & 04:23:00 & 38172 & IC & 03:00:00 & 03:05:00 \\
\hline 93150 & $\mathrm{KM}$ & 00:50:00 & 00:51:00 & 50600 & $\mathrm{R}$ & 04:47:00 & 04:48:00 & 60456 & IC & 04:45:00 & $05: 25: 00$ \\
\hline 21636 & $\mathrm{KM}$ & 01:09:00 & 01:10:00 & 55401 & $\mathrm{R}$ & 05:00:00 & 05:02:00 & 16170 & IC & 04:47:00 & 04:57:00 \\
\hline 38170 & TLK & 02:52:00 & 02:54:00 & 59402 & SKM & 05:02:00 & 05:03:00 & 69300 & KD & 05:00:00 & 05:05:00 \\
\hline 19891 & $\mathrm{KM}$ & 03:12:00 & 03:17:00 & 95711 & SKM & 05:02:00 & 05:03:00 & 69751 & $\mathrm{KD}$ & 05:06:00 & 05:10:00 \\
\hline 97151 & $\mathrm{KM}$ & 03:17:00 & 03:18:00 & 5600 & IC & 05:17:00 & 05:20:00 & 54170 & TLK & 05:20:00 & 05:37:00 \\
\hline 99880 & SKW & 03:34:00 & 03:46:00 & & $\ldots$ & $\ldots$ & $\ldots$ & 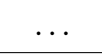 & $\ldots$ & $\ldots$ & $\ldots$ \\
\hline 12711 & $\mathrm{KM}$ & 03:56:00 & 04:05:00 & \multicolumn{4}{|c|}{ Poznań Główny } & \multicolumn{4}{|c|}{ Katowice } \\
\hline 97153 & $\mathrm{KM}$ & 04:19:00 & 04:20:00 & 45170 & TLK & 01:37:00 & 01:57:00 & 14103 & TLK & 00:01:00 & 00:10:00 \\
\hline 99580 & SKW & 04:21:00 & 04:22:00 & 18170 & TLK & 02:05:00 & 02:25:00 & 36170 & TLK & 01:48:00 & 02:07:00 \\
\hline 19601 & $\mathrm{KM}$ & 04:32:00 & 04:36:00 & 81170 & TLK & 02:13:00 & 02:33:00 & 60456 & IC & 01:48:00 & 02:07:00 \\
\hline 93110 & KM & 04:36:00 & 04:37:00 & 54170 & TLK & 02:20:00 & 02:41:00 & 60457 & IC & 02:02:00 & 02:18:00 \\
\hline 99300 & SKW & 04:39:00 & 04:40:00 & 77113 & KW & 05:02:00 & 05:12:00 & 63170 & TLK & 02:02:00 & 02:18:00 \\
\hline 99582 & SKW & 04:45:00 & 04:46:00 & 77384 & KW & 05:14:00 & 05:21:00 & 41102 & TLK & 04:10:00 & 04:15:00 \\
\hline 91850 & $\mathrm{KM}$ & 04:47:00 & 04:48:00 & 38172 & IC & 05:20:00 & 05:54:00 & 83172 & IC & 04:16:00 & 04:21:00 \\
\hline$\ldots$ & $\ldots$ & $\ldots$ & $\ldots$ & $\ldots$ & $\ldots$ & $\cdots$ & $\cdots$ & $\cdots$ & $\cdots$ & $\cdots$ & $\cdots$ \\
\hline
\end{tabular}

Source: own study based on [26].

The following train connections are considered for the train types in question:

- Provincial agglomeration transport: SKM (Fast Urban Rail in Tri-city), SKW (Fast Warsaw Rail),

- National Provincial: R (Regio), KM (Kolej Mazowiecka), KD (Kolej Dojazdowa), KW (Kolej Wielkopolska), KS (Koleje Śląskie)

- National Provincial fast trains: TLK (Twoje Linie Kolejowe), IC (Inter City),

- Express Inter City: EIC (Express InterCity), EIP (Ekspress Intercity Premium).

For the preliminary analysis of the results of the proposed optimization, simplified traction characteristics of locomotives and multiple units were assumed (considering the commercial speed, braking deceleration, and start-up acceleration) without being broken down into individual types of traction units. These data can be included and updated when available (Table 2). The operating reserve and the minimum passenger replacement time were assumed according to the recommendations in [34].

Table 2. Simplified train traction characteristics data and timetable time reserve requirements.

\begin{tabular}{|c|c|c|c|c|c|c|c|}
\hline Type of Train & $\begin{array}{c}\text { Commercial } \\
\text { Speed } \\
\mathbf{v}_{\mathbf{h}}[\mathrm{km} / \mathrm{h}]\end{array}$ & $\begin{array}{c}\text { Acceleration of } \\
\text { Braking } \\
a_{r}\left[\mathrm{~m} / \mathrm{s}^{2}\right]\end{array}$ & $\begin{array}{c}\text { Duration of } \\
\text { Braking } \\
t_{h} \text { [h:min:sek] }\end{array}$ & $\begin{array}{l}\text { Acceleration } \\
\qquad a_{r}\left[\mathrm{~m} / \mathrm{s}^{2}\right]\end{array}$ & $\begin{array}{c}\text { Duration of } \\
\text { Accelerating } \\
t_{\mathrm{r}} \text { [h:min:sek] }\end{array}$ & $\begin{array}{c}\text { Service Time } \\
\text { Reserve } \\
\mathrm{T}_{\mathrm{B}} \text { [h:min:sek] }\end{array}$ & $\begin{array}{c}\text { Passengers } \\
\text { Transfer Time } \\
\mathrm{T}_{\mathrm{wp}}[\mathrm{h}: \mathrm{min}: \mathrm{sek}]\end{array}$ \\
\hline SKM/SKW & 80 & 0.8 & $00: 00: 29$ & 1.6 & 00:00:15 & $00: 02: 30$ & 00:00:30 \\
\hline $\mathrm{R} / \mathrm{KM} / \mathrm{KD} / \mathrm{KW} / \mathrm{KS}$ & 100 & 0.8 & 00:00:35 & 1.6 & 00:00:18 & 00:02:30 & 00:01:00 \\
\hline TLK & 120 & 0.8 & $00: 00: 42$ & 1.6 & $00: 00: 22$ & 00:02:00 & 00:01:00 \\
\hline IC & 120 & 0.8 & 00:00:42 & 1.6 & 00:00:22 & 00:02:00 & 00:02:00 \\
\hline EIC & 160 & 0.8 & $00: 00: 56$ & 1.6 & 00:00:29 & 00:01:30 & 00:02:00 \\
\hline EIP & 200 & 0.8 & 00:01:10 & 1.6 & 00:00:35 & 00:01:30 & 00:02:00 \\
\hline
\end{tabular}

Source: own study based on [40].

Due to the technical limitations of the Solver tool used, the analysis was assumed to be performed for a limited, equal number of trains at each station. As a representation of each station, the first 50 passenger trains passing through and served by a given station (i.e., trains that do not finish or start running, whose traction characteristics include both start-up and braking) during a given day were assumed. Taking into account the different characteristics of the stations, this resulted in a different density of analyzed trains in the resulting time window, which is shown in Figure 3. 


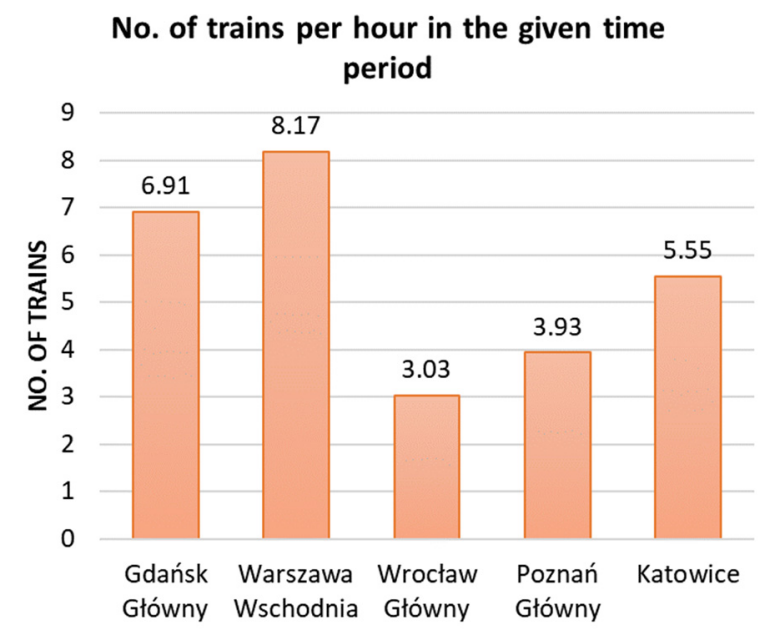

Figure 3. Number of trains served by the station in a given time period. Source: own study.

\subsection{Single-Criterion Optimization}

The results shown in Figure 4 were obtained through single-criterion optimization, using function (8) - looking for the largest number of interactions involving energy vehicle cooperation, and function (9)-looking for the longest duration of energy cooperation.

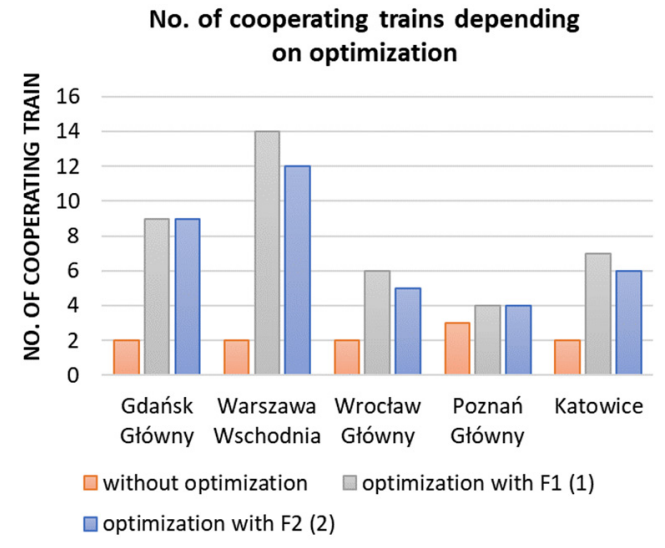

(a)

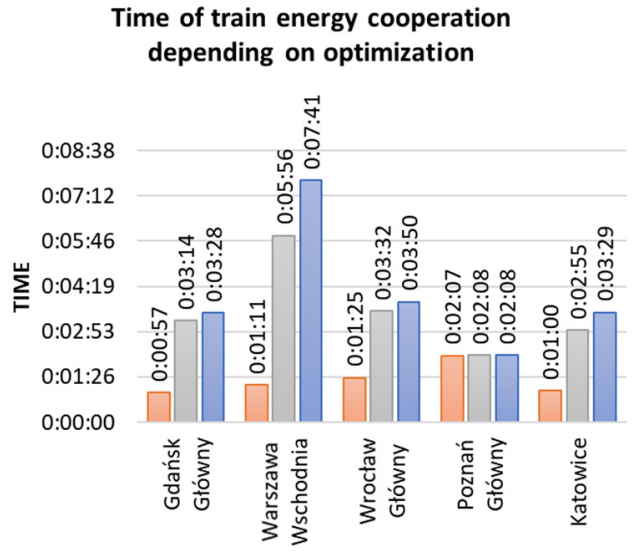

(b)

Figure 4. Summary of the results of single-criterion optimization using (a) $F_{1}$ (1) and (b) $F_{2}$ (2). Source: own study.

The presented results illustrate that at each of the stations for the analyzed trains, without any changes in the timetable, there were traffic situations that enabled energy cooperation among trains that lasted from $57 \mathrm{~s}$ at the Gdańsk Główny station to $2 \mathrm{~min}$ and $25 \mathrm{~s}$ at the Poznań Główny station. As a result of the optimization, it was possible to increase the number of participating trains, and the duration of energy cooperation increased sevenfold in the case of the Warszawa Wschodnia station. In each of the analyzed cases, it was found that at least equal or better values of the number of cooperating vehicles were obtained using the function described in (8) than in (9), while better results regarding the length of the cooperation time were obtained using (9) as the objective function, which is consistent with the assumption. It is worth noting that a larger number of cooperating trains does not necessarily mean a longer cooperation time.

From the analyses using objective functions (8) and (9), it can be additionally observed in Figure 5 how much, within an acceptable range, the arrival and departure times of the trains need to be amended in order to increase the number of cooperating trains or the duration of the energy cooperation. 


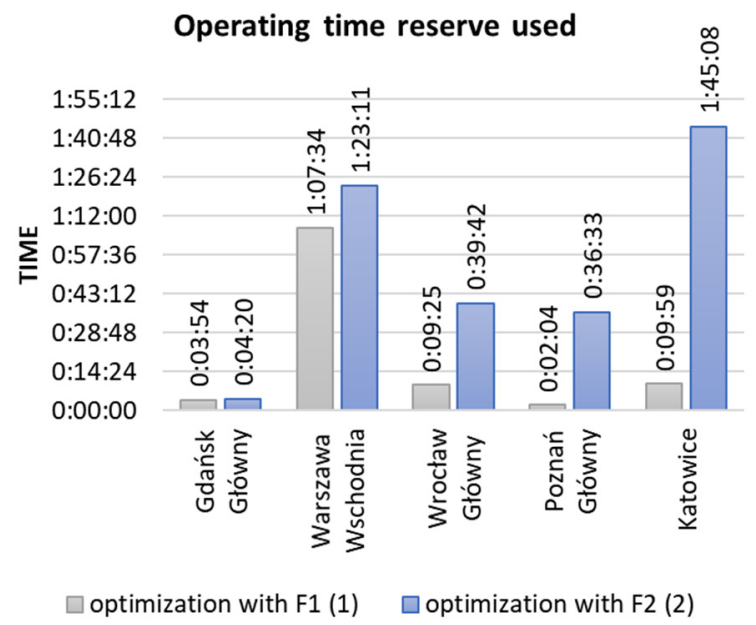

Figure 5. Operating time reserve used for $F_{1}(1)$ and $F_{2}$ (2). Source: own study.

It is worth noting that with the performed single-criterion optimization for increasing the energy efficiency of vehicle cooperation, it is not possible to demonstrate a direct relationship between the need to use the operating time reserve in the timetable and the density of train traffic at a given station, as shown in Figure 3. However, it can be observed that the largest operating reserve of the timetable is used much more often when looking for the largest possible number of cooperating trains than when looking for the longest cooperation time between them.

\subsection{Multi-Criteria Optimization}

During multi-criteria optimization, two different global objective functions (24) and nine different sets of weight factors for each criterion were used (Table 3).

Table 3. Sets of weight factors for optimization (24).

\begin{tabular}{|c|c|c|c|c|c|}
\hline & Weight & $\begin{array}{l}\text { No. of Cooperating Trains } \\
\qquad w_{1}\end{array}$ & $\begin{array}{c}\text { Length of Time for Energetic } \\
\text { Trains Cooperation } \\
\mathbf{w}_{2}\end{array}$ & $\begin{array}{c}\text { Arrival Delays } \\
\qquad \mathbf{w}_{3} \\
\end{array}$ & $\begin{array}{c}\text { Departure Delays } \\
\qquad \mathbf{w}_{4}\end{array}$ \\
\hline \multirow{9}{*}{ FC (24) } & Set of weight factor \#1 & - & 0.6 & 0.3 & 0.1 \\
\hline & Set of weight factor \#2 & - & 0.6 & 0.2 & 0.2 \\
\hline & Set of weight factor \#3 & - & 0.6 & 0.1 & 0.3 \\
\hline & Set of weight factor \#4 & 0.2 & 0.4 & 0.3 & 0.1 \\
\hline & Set of weight factor \#5 & 0.2 & 0.4 & 0.2 & 0.2 \\
\hline & Set of weight factor \#6 & 0.2 & 0.4 & 0.1 & 0.3 \\
\hline & Set of weight factor \#7 & 0.4 & 0.2 & 0.3 & 0.1 \\
\hline & Set of weight factor \#8 & 0.4 & 0.2 & 0.2 & 0.2 \\
\hline & Set of weight factor \#9 & 0.4 & 0.2 & 0.1 & 0.3 \\
\hline
\end{tabular}

Source: own study.

Using Formula (24), in the first case (set 1), the most important criterion was the length of energy cooperation (which is justified in the context of the research conducted) and it was assigned the weight factor $\mathrm{w}_{2}=0.6$, while the arrival and departure delay times were considered less important and were assigned the weight factors $\mathrm{w}_{3}=0.3$ and $\mathrm{w}_{4}=0.1$, respectively.

In the next case (set 2), the importance of the criterion of the length of energy cooperation was left unchanged, but the delay of train arrival and departure at a given station were considered to be of equal importance, and consequently, $\mathrm{w}_{3}=0.2$ and $\mathrm{w}_{4}=0.2$ were adopted.

In the third case (set 3), using Equation (24), the value $\mathrm{w}_{2}=0.6$ was still left, but the situation was reversed with respect to the first case and it was considered that it would be more beneficial at a given station to have a longer train arrival delay while keeping the 
train departure punctuality at the best level possible. Consequently, $\mathrm{w}_{3}=0.1$ and $\mathrm{w}_{4}=0.3$ were assumed.

The results obtained from the above are shown in Figure 6.

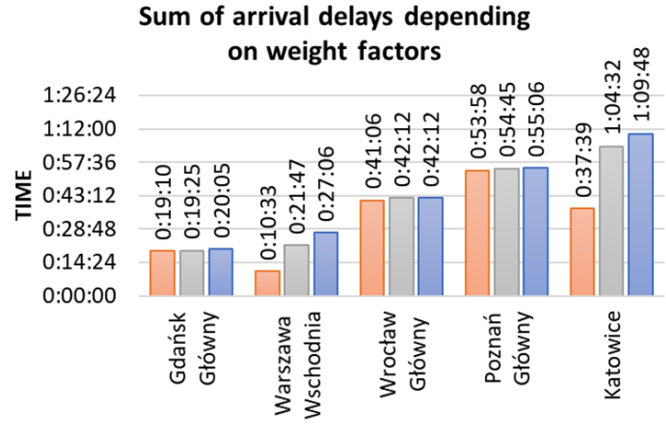

$\square$ set of weight factors \#1 $\square$ set of weight factors \#2 $\square$ set of weight factors \#3

(a)

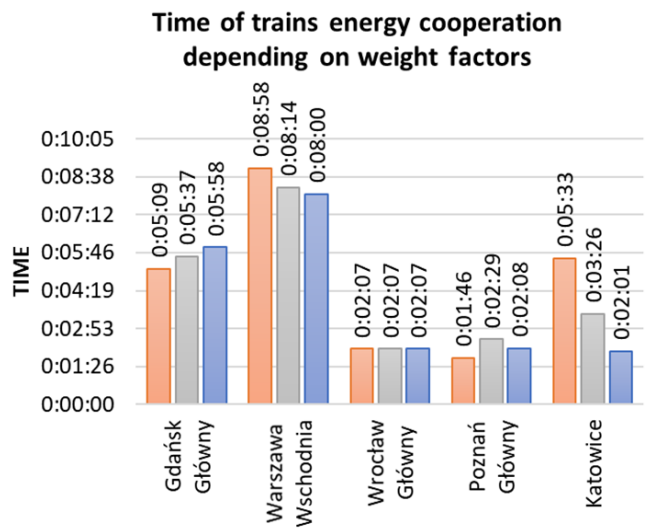

(c)

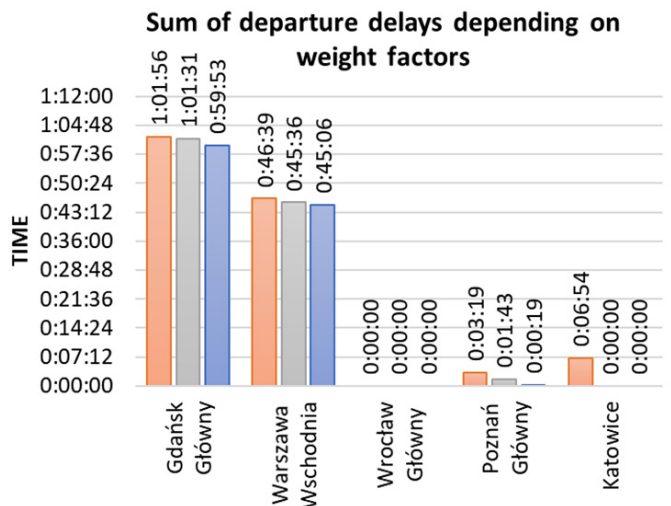

(b)

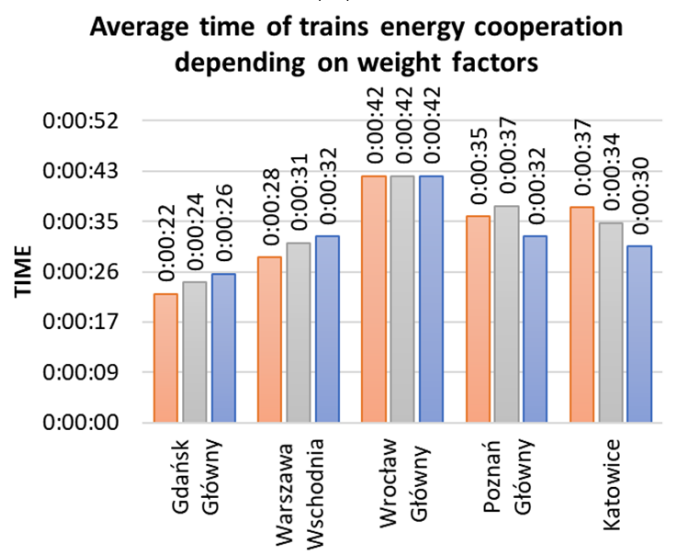

(d)

Figure 6. Summary of the results of the individual component functions of multi-criteria optimization (24) according to the adopted weight factors 1-3. (a) Sum of arrival delays depending on weight factors. (b) Sum of departure delays depending on weight factors. (c) Time of trains energy cooperation depending on weight factors. (d) Average time of trains energy cooperation depending on weight factors. Source: own study.

From the above graphs, it can generally be concluded that the results related to arrival and departure delay times change according to the assumed weight factors: i.e., as the weight factor $\mathrm{w}_{2}$ decreases, the arrival delay time increases, while as the weight $\mathrm{w}_{3}$ increases, the total departure delay time decreases. However, it should be noted that the obtained cooperation time itself not only relates to the adopted values of the weight factors, but also to the very traffic characteristics occurring at a given station. It is best illustrated with the example of the Gdańsk Główny and Katowice stations, where the trend of the received values of cooperation time and average cooperation time per cooperating train, depending on the weight factors for particular criteria, is the opposite.

Using the objective function (24) extended with the criterion of the number of cooperating trains, six different sets of weight factors for each criterion were applied. In accordance with the priority assumptions of the conducted research, in each of the six sets it was assumed that $\mathrm{w}_{1}+\mathrm{w}_{2}>\mathrm{w}_{3}+\mathrm{w}_{4}$ and, similarly to the optimization that did not take into account the number of cooperating trains, a variable hierarchy was introduced between the weight factors $\mathrm{w}_{1}$ and $\mathrm{w}_{2}$ and between the weight factors $\mathrm{w}_{3}$ and $\mathrm{w}_{4}$.

In the first case (set 4), the most important criterion was the length of energy cooperation among trains, which was assigned the weight factor of $\mathrm{w}_{2}=0.2$, while the number of 
cooperating trains was assumed to be less important in the context of energy cooperation, assuming $\mathrm{w}_{1}=0.4$. In the context of timetable delays, arrival delays were considered more important and departure delays less important, and were assigned the weight factors $\mathrm{w}_{2}=0.3$ and $\mathrm{w}_{3}=0.1$, respectively.

In the following cases (set 5 and set 6), the value of importance of $\mathrm{w}_{1}$ and $\mathrm{w}_{2}$ were left unchanged, but once it was considered that train arrival and departure delays at a given station would be equally important, and therefore $\mathrm{w}_{3}=0.2$ and $\mathrm{w}_{4}=0.2$ were adopted. The second time it was assumed that a greater train arrival delay at a given station would be more beneficial while keeping the train departure punctuality as good as possible. Consequently, $\mathrm{w}_{3}=0.1$ and $\mathrm{w}_{5}=0.3$ were assumed.

Changing the importance in the context of train energy cooperation, and considering that the number of cooperating trains at a station is more important than the total time of train cooperation (which may prevent the accumulation of delays to individual trains), the relationship between $\mathrm{w}_{1}$ and $\mathrm{w}_{2}$ was changed, taking their values to 0.2 and 0.4 , respectively (set 7-9). This option again assumes changes to the weight factors $w_{2}$ and $w_{3}$, as described above.

The results obtained from the above are shown in Figure 7.

No. of cooperating trains depending on weight factors

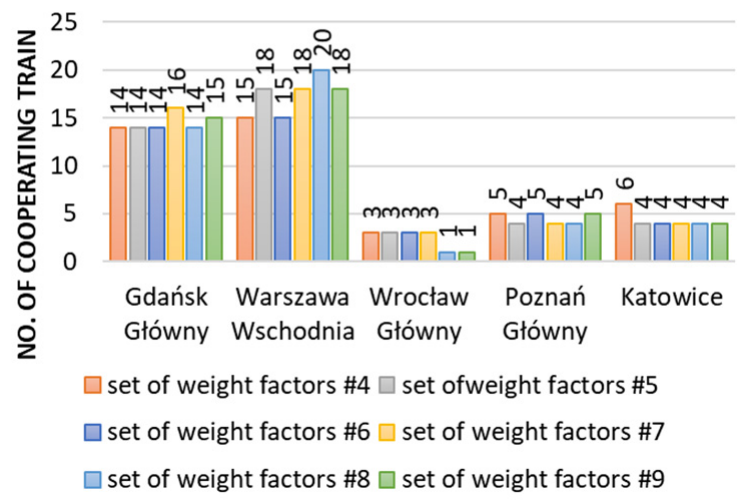

(a)

Total arrival delay depending on weight factors

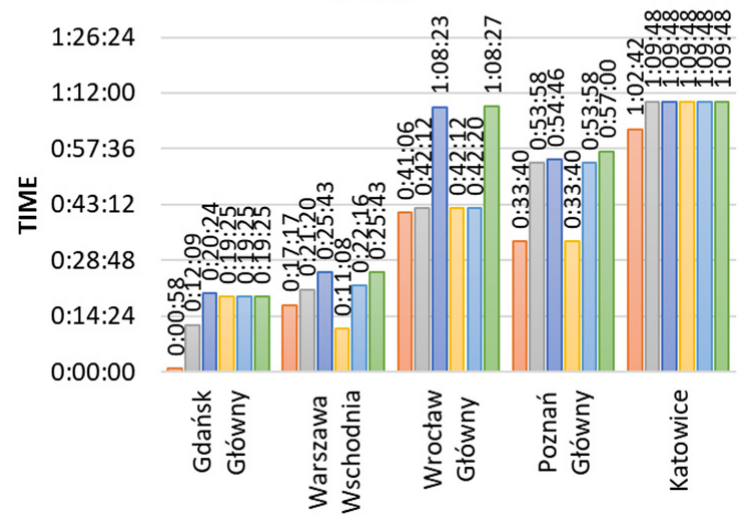

(c)

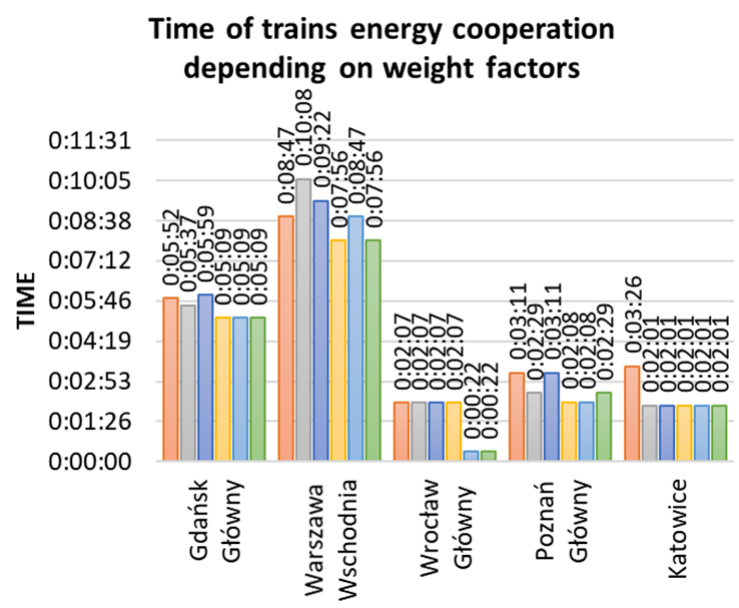

(b)

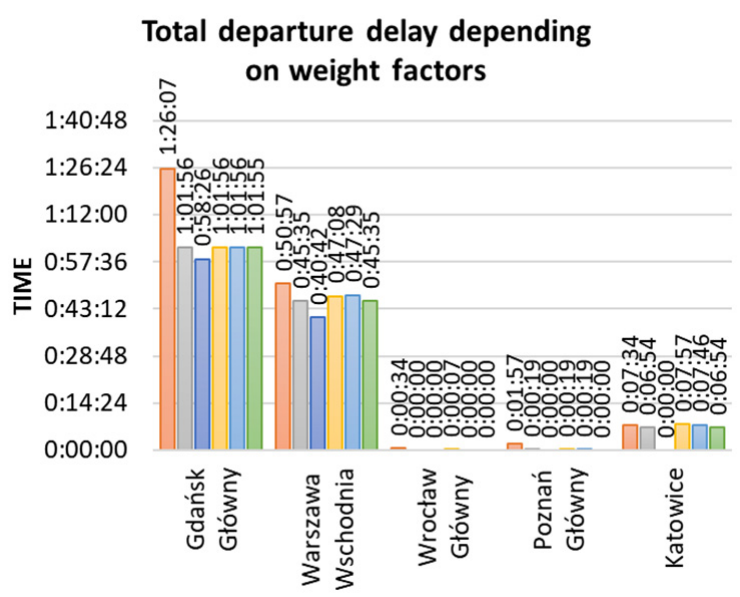

(d)

Figure 7. Summary of the results of the individual component functions of multi-criteria optimization (24) according to the adopted weight factors 4-9. (a) No. of cooperating train depending on weight factors. (b) Time of trains energy cooperation depending on weight factors. (c) Total arrival delay depending on weight factors. (d) Total departure delay depending on weight factors. Source: own elaboration. 
From the above results, it can generally be concluded that the values related to arrival and departure delay times change according to the assumed weight factors: i.e., as the weight factor $\mathrm{w}_{2}$ decreases, the arrival delay time remains the same or increases, while as the weight factor $\mathrm{w}_{3}$ increases, the total departure delay time decreases or remains the same. In general, the correlation between the results and the value of the individual weight factors is also evident with the number of trains and the cooperation time. However, attention should be paid to discrepancies at stations where the number of served trains in the assumed time window is relatively low. This is best seen in the example of the Wrocław Główny station, where worse results were obtained when the higher importance of the function component corresponded to the number of cooperating trains compared with lower importance (set of weight factors no. 4-6 and 7-9).

It is also interesting that for the stations that served a larger number of trains during the assumed time window, i.e., Gdańsk Główny and Warszawa Wschodnia, the results were influenced mainly by the delays to departures, not arrivals. The opposite situation occurred in the case of optimization results obtained at the Wrocław Główny, Poznan Główny, and Katowice stations, where the number of trains analyzed was much smaller.

\section{Discussion and Conclusions}

Using the proposed optimization model and algorithm, and based on the obtained results, it can be concluded that in terms of organization, it is possible to increase the effects of energy cooperation among trains (increase the number of cooperating trains and increase the duration of energy cooperation). This can be achieved, among other approaches, by delaying the arrival or departure of a given train at a particular station using the operating time reserve included in the timetable. Assuming no unforeseeable exceptional situations on the rail network (e.g., accidental delay), this should not cause significant delays to the train schedule.

In the proposed approach, both single and multi-criteria optimizations can be applied, taking into account the appropriate priorities (weight factors of the different objective functions), which are particularly important from the point of view of the operator, the infrastructure manager, and the passenger. The Solver tool, available in Excel, was used to perform the optimization.

The results obtained suggest that the proposed model and algorithm meet the assumptions set; i.e., it can find a locally optimal solution that is better than the existing situation in terms of the number of cooperating trains or the duration of cooperation. The results are shown in Figure 8.

The above summary also confirms that with the assumptions made in the introduction, there are more opportunities for energy cooperation at stations with a high density of served trains and occurrence of suburban train traffic. Additionally, it is worth noting that better results were achieved using multi-criteria optimization, which is most likely due to the Solver optimization tool used, which has significant limitations in terms of methods of searching for the optimal solution. The exception is the Wrocław Główny station, where better results were observed using a single-criterion objective function. It should be supposed that it is possible to find even better solutions using another method of searching for the optimal solution.

One of the main disadvantages of the developed algorithm is the fact that optimization does not give an exact value of the amount of energy that can be recovered and used immediately, only information regarding when it will be more or less. With this method, it is currently impossible to obtain the exact value of the energy and financial savings. In order to determine the exact values, it would be necessary to calculate the so-called theoretical drive for new arrival and departure times.

The next stage of the research will be the design of an extensive tool using, for example, MATLAB and others optimization methods, such as genetic or swarm algorithms. A wider range of data will also be used, and will take into account the trains starting and finishing 
their run at a given station and comparing them with the real values of the energy recovered in the energy balance of the analyzed train runs.

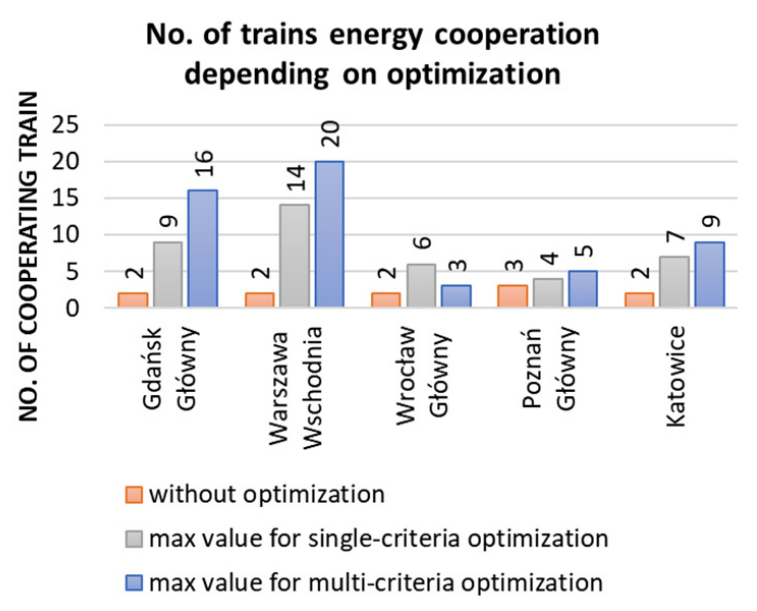

(a)

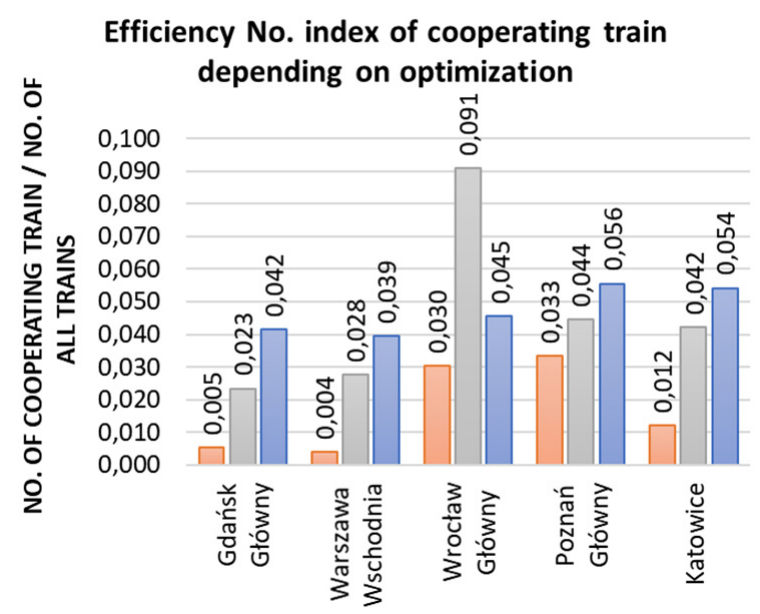

(c)

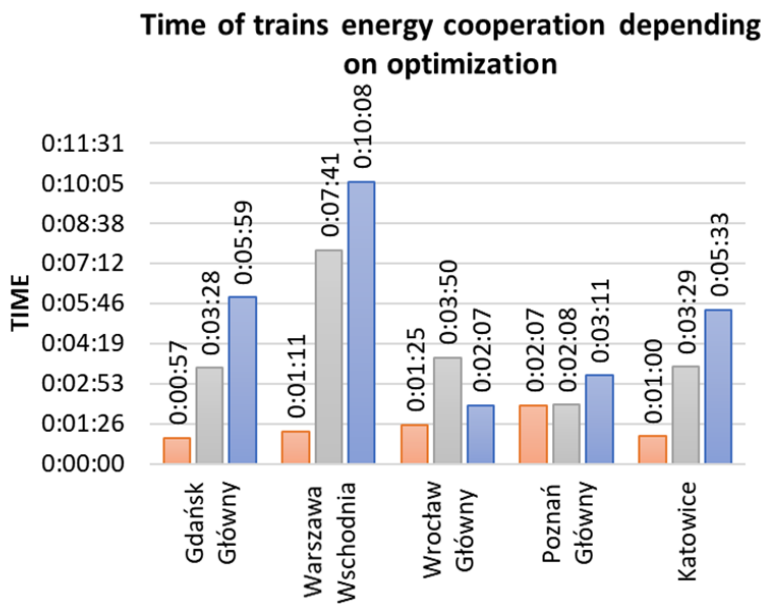

(b)

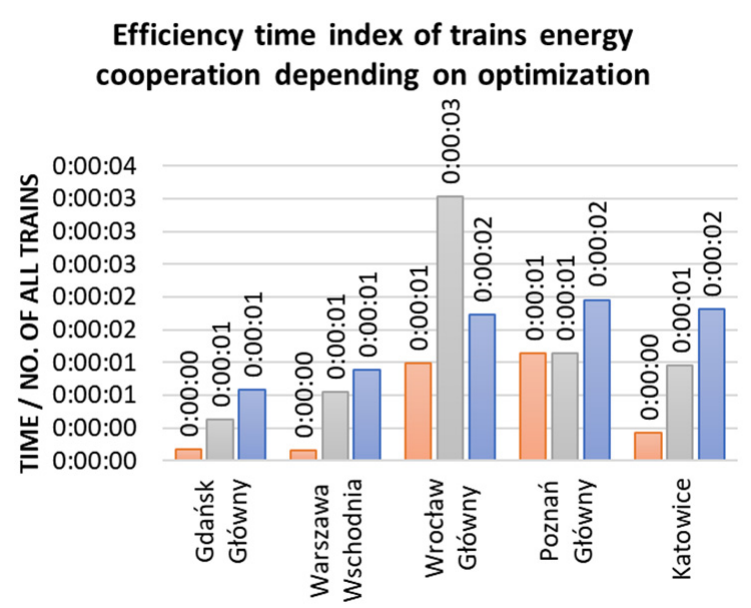

(d)

Figure 8. Summary of the final results depending on the optimization used. (a) No. of trains energy cooperation depending on optimization. (b) Time of trains energy cooperation depending on optimization. (c) Efficiency No. index of cooperating train depending on optimization. (d) Efficiency time index of trains energy cooperation depending on optimization. Source: own study.

Author Contributions: Conceptualization, M.U. and E.K.-C.; data curation, M.U.; formal analysis, M.U. and E.K.-C.; funding acquisition, E.K.-C.; methodology, M.U. and E.K.-C.; resources, M.U.; software, M.U.; supervision, E.K.-C.; validation, M.U.; visualization, M.U.; writing-original draft, M.U.; writing-review and editing, M.U. and E.K.-C. All authors have read and agreed to the published version of the manuscript.

Funding: The research was funded by the Warsaw University of Technology within the IDUB-Open Science Program.

Institutional Review Board Statement: Not applicable.

Informed Consent Statement: Informed consent was obtained from all subjects involved in the study.

Data Availability Statement: Data available in a publicly accessible repository.

Conflicts of Interest: The authors declare no conflict of interest. The funders had no role in the design of the study; in the collection, analyses, or interpretation of the data; in the writing of the manuscript; or in the decision to publish the results. 


\section{References}

1. European Environment Agency. Adaptation of Transport to Climate Change in Europe; EEA Report no 8/2014; European Environment Agency: Luxemburg, 2014.

2. Batrancea, I.; Batrancea, L.; Nichita, A.; Gaban, L.; Masca, E.; Fatacean, G.; Moscviciov, A. An Econometric Approach on Production, Costs and Profit in Romanian Coal Mining Enterprises. Econ. Res.-Ekon. Istraz. 2019, 32, 1019-1063. [CrossRef]

3. Ma, F.; Wang, W.; Sun, Q.; Liu, F.; Li, X. Ecological Pressure of Carbon Footprint in Passenger Transport: Spatio-Temporal Changes and Regional Disparities. Sustainability 2018, 10, 317. [CrossRef]

4. Moretti, L.; Loprencipe, G. Climate Change and Transport Infrastructures: State of the Art. Sustainability 2018, 10, 4098. [CrossRef]

5. Gaj, K.; Miller, U.; Sówka, I. Progressing Climate Changes and Deteriorating Air Quality as One of the Biggest Challenges of Sustainable Development of the Present Decade in Poland. Sustainability 2020, 12, 6367. [CrossRef]

6. Izdebski, M.; Jacyna, M. An Efficient Hybrid Algorithm for Energy Expenditure Estimation for Electric Vehicles in Urban Service Enterprises. Energies 2021, 14, 2004. [CrossRef]

7. European Commision. Roadmap to a Single European Transport Area-Towards a Competitive and Resource Efficient Transport System European Commision: Brusseles, Belgium, 2011.

8. European Commision. Sustainable and Smart Mobility Strategy-Putting European Transport on Track for the Future; European Commision: Brusseles, Belgium, 2011.

9. Batrancea, I.; Batrancea, L.; Maran Rathnaswamy, M.; Tulai, H.; Fatacean, G.; Rus, M.-I. Greening the Financial System in USA, Canada and Brazil: A Panel Data Analysis. Mathematics 2020, 8, 2217. [CrossRef]

10. Batrancea, L. An Econometric Approach Regarding the Impact of Fiscal Pressure on Equilibrium: Evidence from Electricity, Gas and Oil Companies Listed on the New York Stock Exchange. Mathematics 2021, 9, 630. [CrossRef]

11. García-Olivares, A.; Solé, J.; Samsó, R.; Ballabrera-Poy, J. Sustainable European Transport System in a 100\% Renewable Economy. Sustainability 2020, 12, 5091. [CrossRef]

12. Popescu, M.; Bitoleanu, A. A Review of the Energy Efficiency Improvement in DC Railway Systems. Energies 2019, 12, 1092. [CrossRef]

13. Iannuzzi, D.; Pagano, E.; Tricoli, P. The Use of Energy Storage Systems for Supporting the Voltage Needs of Urban and Suburban Railway Contact Lines. Energies 2013, 6, 1802-1820. [CrossRef]

14. Mayrink, S., Jr.; Oliveira, J.G.; Dias, B.H.; Oliveira, L.W.; Ochoa, J.S.; Rosseti, G.S. Regenerative Braking for Energy Recovering in Diesel-Electric Freight Trains: A Technical and Economic Evaluation. Energies 2020, 13, 963. [CrossRef]

15. Jacyna, M.; Szczepański, E.; Izdebski, M.; Jasiński, S.; Maciejewski, M. Characteristics of event recorders in Automatic Train Control systems. Arch. Transp. 2018, 46, 61-70. [CrossRef]

16. González-Gil, A.; Palacin, R.; Batty, P. Sustainable urban rail systems: Strategies and technologies for optimal management of regenerative braking energy. Energy Convers. Manag. 2013, 75, 374-388. [CrossRef]

17. Urbaniak, M.; Kardas-Cinal, E.; Jacyna, M. Optimization of Energetic Train Cooperation. Symmetry 2019, 11, 1175. [CrossRef]

18. Urbaniak, M.; Kardas-Cinal, E. Optimization of using recuperative braking energy on a double-track railway line. Transp. Res. Procedia 2019, 40, 1208-1215. [CrossRef]

19. Caprara, A.; Fischetti, M.; Toth, P. Modelling and Solving the Train Timetabling Problem. Oper. Res. 2002, 50, 851-861. [CrossRef]

20. Laporte, G.; Barnhart, C. Handbooks in Operations Research and Management Science: Transportation; Elsevier: Amsterdam, The Netherlands, 2007; Volume 14, 784p.

21. Peeters, L. Cyclic Railway Timetable Optimization; Erasmus Research Institute of Management: Rotterdam, The Netherlands, 2003.

22. Albrecht, T.; Oettich, S. A New Integrated Approach to Dynamic Schedule Synchronization and Energy Saving Train Control, Computers in railways VIII; WIT Press: Southampton, UK, 2002; pp. 847-856.

23. Bengtsson, L.; Galia, R.; Gustafsson, T.; Hjorring, C.; Kohl, N. Railway Crew Pairing Optimization. In Algorithmic Methods for Railway Optimization; Geraets, F., Kroon, L., Schoebel, A., Wagner, D., Zaroliagis, C.D., Eds.; Lecture Notes in Computer Science; Springer: Berlin/Heidelberg, Germany, 2007; Volume 4359, pp. 126-144.

24. Bocharnikov, Y.V.; Goodman, C.J.; Hillmansen, S.; Roberts, C.; Tobias, A.M. Optimal driving strategy for traction energy saving on DC suburban railways. Electr. Power Appl. 2007, 5, 675-682. [CrossRef]

25. Pazdro, P.; Karwowski, K.; Czucha, J.; Mizan, M.; Kamonciak, A.; Skibicki, J. Optymalizacja Efektów Hamowania Odzyskowego w Komunikacji Miejskiej Przez Sterowanie Adaptacyjne; State Committee for Scientific Research (KBN) Report: Gdansk, Poland, 2003. (In Polish)

26. González-Gil, A.; Palacin, R.; Batty, P.; Powell, J. Energy-efficient urban rail systems: Strategies for an optimal management of regenerative braking energy. In Proceedings of the Transport Research Arena 2014, Paris, France, 14-17 April 2014.

27. Pena-Alcaraz, M.; Fernandez, A.; Cucala Paloma, A.; Ramos, A.; Pecharromán, R. Optimal underground timetable design based on power flow for maximizing the use of regenerative-braking energy. J. Rail Rapid Transit 2011, 226, 397-408. [CrossRef]

28. Nasri, A.; Fekri Moghadam, M.; Mokhtari, H. Timetable optimization for maximum usage of regenerative energy of braking in electrical railway systems. In Proceedings of the SPEEDAM 2010, Pisa, Italy, 14-16 June 2010.

29. Yang, X.; Ning, B.; Li, X.; Tang, T. A Two-Objective Timetable Optimization Model in Subway Systems. IEEE Trans. Intell. Transp. Syst. 2014, 5, 1913-1921. [CrossRef]

30. Zapata-Barrero, R.; Tackoen, X.; van Mirelo, J. Stationary or onboard energy storage systems for energy consumption reduction in a metro network. Proc. Inst. Mech. Eng. Part F J. Rail Rapid Transit 2010, 224, 207-225. [CrossRef] 
31. Chymera, M.; Renfrew, A.; Barnes, M. Analizing the potential of energy storage on electrified transit systems. In Proceedings of the World Congress on Railway Research-WCRR 2008, Seoul, Korea, 18-22 May 2008.

32. Dominguez, M.; Cucala, A.P.; Fernandez, A.; Pecharroman, R.R.; Blanquer, J. Energy efficiency on train control—Design of metro ATO driving and impact of energy accumulation devices. In Proceedings of the World Congress on Railway Research-WCRR 2011, Lille, France, 22-26 May 2011.

33. Teymourfar, R.; Asaei, B.; Iman-Eini, H.; Nejati fard, R. Stationary super-capacitor energy storage system to save regenerative braking energy in metro line. Energy Convers. Manag. 2012, 56, 206-214. [CrossRef]

34. Warin, Y.; Lanselle, R.; Thiounn, M. Active substation. In Proceedings of the World Congress on Railway Research-WCRR 2011, Lille, France, 22-26 May 2011.

35. Garcia-Ortega, M.J.; Ibaiondo, H. Kinetic energy recovery on railway systems with feedback to the grid. In Proceedings of the World Congress on Railway Research-WCRR 2011, Lille, France, 22-26 May 2011.

36. Cornic, D. Efficient recovery of braking energy through a reversible dc substation. In Proceedings of the Electrical Systems for Aircraft, Railway and Ship Propulsion (ESARS) Conference, Bologna, Italy, 19-21 October 2010. [CrossRef]

37. Urząd Transportu Kolejowego. Największe Dworce Kolejowe w Polsce; Urząd Transportu Kolejowego: Warszawa, Poland, 2020. (In Polish)

38. PKP Informatyka \& PKP S.A. Your Routeplanner. Available online: http:/ / old.rozklad-pkp.pl/ (accessed on 20 September 2021).

39. Google Maps. Available online: https://www.google.com/maps/ (accessed on 20 September 2021).

40. PKP Polskie Linie Kolejowe. Instrukcja o Rozkładzie Jazdy Pociagów Ir-11; PKP Polskie Linie Kolejowe: Warszawa, Poland, 2015. (In Polish) 